\title{
Article
}

\section{FRPM'07 special edition}

\author{
Kandola, B. K. and Hull, T Richard
}

Available at http://clok.uclan.ac.uk/1069/

Kandola, B. K. and Hull, T Richard ORCID: 0000-0002-7970-4208 (2008)

FRPM'07 special edition. Polymer degredation and Stability, 93 (11). p. 1985. ISSN 0141-3910

It is advisable to refer to the publisher's version if you intend to cite from the work. http://dx.doi.org/10.1016/j.polymdegradstab.2008.07.014

For more information about UCLan's research in this area go to http://www.uclan.ac.uk/researchgroups/ and search for < name of research Group>.

For information about Research generally at UCLan please go to http://www.uclan.ac.uk/research/

All outputs in CLoK are protected by Intellectual Property Rights law, including Copyright law. Copyright, IPR and Moral Rights for the works on this site are retained by the individual authors and/or other copyright owners. Terms and conditions for use of this material are defined in the policies page.

\section{CLoK}

Central Lancashire online Knowledge www.clok.uclan.ac.uk

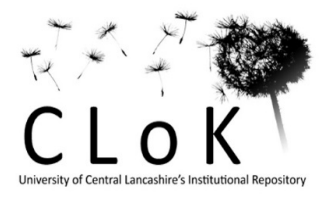


Kandola, B.K. and Hull, T.R. "FRPM07 Special Edition”. Polymer Degradation and Stability, 93, 1985, 2008

\section{Editorial \\ FRPM'07 special edition}

This special edition of Polymer Degradation and Stability follows the scientific paper presentations and subsequent discussions which took place at the $11^{\text {th }}$ Meeting on Fire Retardant Polymers (FRPM'07), held in Bolton, United Kingdom in July 2007. This is the latest of the series organised every two years by different academic research groups in Europe, and follows the tradition of meetings held in Berlin, Germany (2005); Lille, France (2003); Alessandria, Italy (2001); Lille, France (1999); Greenwich, UK (1997); Salford, UK (1995) and so on.

The conference, which originally started as a European meeting, over the years has become truly international. This particular meeting attracted over 200 scientists from 20 countries, representing both industry and academia. This shows that the fire safety issues stimulated in Europe in 1980s by the introduction of regulatory legislation and continuously revised to meet new products and their applications, are being positively addressed.

From the materials point of view, the fire safety issues can be summarised as:

- The use of fire safe materials in various industries especially transport, furnishings, electrical and electronics and construction.

- Fire behaviour of combinations of materials

- Balance of fire safety for humans and property against environmental and legislative considerations including toxicity of emissions and low smoke production.

- Fire safety legislation for mandatory use of fire safe materials in key application areas

- Public awareness of potential fire hazards, flammable products and fire safety

Development of new fire retardant materials is an important component of the fire safety. For this there is a need for a greater knowledge of the complex chemistry of fire retardant behaviour, which also depends upon the complex physical and chemical phenomena occurring during polymer combustion in fire conditions. The approach can be theoretical as well, where mathematical modelling complements experimental findings and helps in new system development. Polymers, both unmodified and fire retarded, behave differently under different fire conditions, hence, the knowledge of techniques and test methods used to provide the necessary data is also important. The topic is, therefore, multidisciplinary in nature requiring cooperation between scientists from chemistry (polymer, physical and analytical), physics and mathematical modelling backgrounds; manufacturers and regulators.

The conference programme was divided into several sessions, each with a particular theme and consisting of 9 plenary and 10 keynote lectures, which were supported by 40 contributed oral papers and 51 posters. The themes were Assessment of Fire Performance; Fire Retardant Mechanisms; New Fire Retardant Systems; Nanoscience 
and Synergy; Modelling Fire Behaviour; Fire Behaviour of Composites; Aerospace and Transport Applications; Textile Coating and Lamination; Environment, Health and Safety; Testing, Regulation and New Techniques for Studying Fire Behaviour.

This special issue of Polymer Degradation and Stability presents 14 selected articles representative of the work of the conference. About 25 articles have been compiled for a separate publication 'Fire Retardancy of Polymers: New Flame Retardant Strategies and Mechanisms' (Royal Society of Chemistry (RSC), Cambridge, 2009). This book covers the latest development in areas of fire retardant strategies; new fire retardant systems including nanoparticulate fillers; intumescent formulations and their recent applications in bulk polymers, fibres and textiles; test-methods for material flammability; materialspecific aspects of combustion, smoke and toxicity. We trust that this special issue will complement the RSC book in providing fire retardant materials' developers with latest in research and design of new fire retardant materials and understanding their mechanisms of action.

The organising committee of the meeting honoured Prof Dennis Price and Prof Richard Horrocks for their lifetime contributions to the Fire Retardancy. Both are Professors at the University of Bolton and have devoted almost 30 years each to the field. We therefore dedicate this Special Issue to Professors Price and Horrocks.

The $12^{\text {th }}$ Conference is scheduled to take place in September 2009 at the Institute of Natural Fibres, Poznan (Poland). We look forward to meet again to discuss new achievements in area of Fire Retardant Polymers. ( Email: sekretar@inf.poznan.pl)

Baljinder K. Kandola

Centre for Materials Research and Innovation

The University of Bolton

Bolton BL3 5AB

United Kingdom

E-Mail: b.kandola@bolton.ac.uk

T.Richard Hull

Centre for Fire and Hazard Sciences,

School of Forensic and Investigative Sciences,

University of Central Lancashire,

Preston, PR1 2HE

e-mail: trhull@uclan.ac.uk 